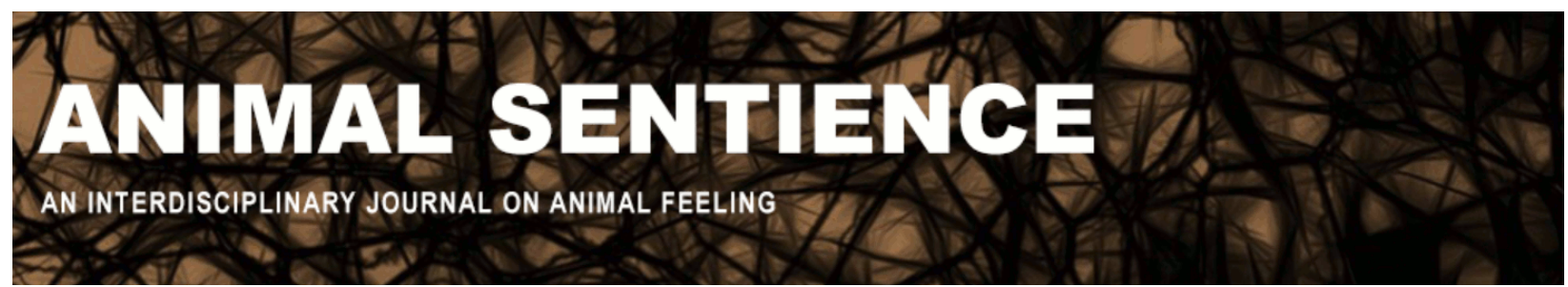

Marino, Lori (2019) "I am not an animal". Animal Sentience 23(40)

DOI: $10.51291 / 2377-7478.1425$

Date of submission: 2019-02-22

Date of acceptance: 2019-02-26

(c) (i)

This article has appeared in the journal Animal

Sentience, a peer-reviewed journal on animal

cognition and feeling. It has been made open access,

free for all, by WellBeing International and deposited

in the WBI Studies Repository. For more information,

please contact

wbisr-info@wellbeingintl.org.

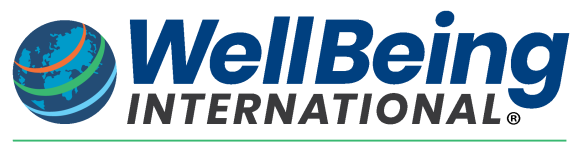

SOLUTIONS FOR PEOPLE, ANIMALS AND ENVIRONMENT 


\author{
"I am not an animal" \\ Commentary on Chapman \& Huffman on Human Difference
}

\title{
Lori Marino
}

The Kimmela Center for Animal Advocacy, Utah

\begin{abstract}
The answer to Chapman \& Huffman's question - "Why do we want to think humans are different?" - lies in the work of Ernest Becker and the social psychology literature known as Terror Management Theory, according to which our deep anxiety about animality and death can drive our need to feel superior to the other animals.
\end{abstract}

Lori Marino is Executive Director of The Kimmela
Center for Animal Advocacy and President of The
Whale Sanctuary Project. She has published over
130 articles, book chapters and articles on
cetacean brain evolution and intelligence, farmed
animal cognition, and the ethics of our
relationship with the other animals. Website

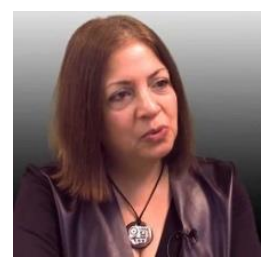

Chapman \& Huffman (2018) (C\&H) ask why we want to think humans are different. After describing a litany of failed criteria for human uniqueness and acknowledging that our propensity to place ourselves above nature is destroying the planet, $\mathrm{C} \& \mathrm{H}$ articulate the pivotal question of why, despite the lack of scientific evidence for our superiority over other species, "the desire to see humans as unique still remains."

A theory advanced by anthropologist Ernest Becker has much insight to offer on this problem. Human exceptionalism may be a deeply rooted subconscious defense against accepting our own animal nature and the ultimate consequence of animality - death.

In The Denial of Death, Becker (1973) suggested that human awareness of personal mortality creates deep subconscious anxiety that influences much of what we do. Our behavior (cultural, religious, social, etc.) becomes a way to deny our biological animality, creating a strong defense against the knowledge that, like all the other animals, "man is a worm and food for worms." Becker exposes the fundamental paradox that despite our vaunted abilities we are still hopelessly entrapped in our creatureliness. The attempt of our species to deny this mortality has brought forth the human rallying cry, "I Am Not an Animal".

Marino and Mountain (2015) argued that our anxiety about mortality has led to an exploitative and ultimately destructive relationship with the rest of nature. The social psychological theory underlying this idea is Terror Management Theory (TMT), according to which we try to cope with the anxiety caused by reminders of our mortality (increases in "mortality salience") by holding fast to cultural ideas that distance us from them (Solomon, Greenberg, and Pyszczynski 1991, 2004). Reminders of our mortality make us wish to remain separate from and superior to the other animals (as well as to other human groups who make us insecure by challenging our cultural assumptions): "[C]ultures promote norms that help people to distinguish 
themselves from animals.... [D]istancing from the rest of the animal kingdom helps humans defend against anxiety associated with awareness of death" (Goldenberg et al. 2001, p. 1).

There is considerable experimental support for TMT (see Solomon, Greenberg, and Pyszczynski 2004; Landau et al. 2007; Greenberg, Solomon, and Arndt 2008, for reviews of the TMT literature). Evidence that increasing mortality salience increases our need for distance from the other animals comes from several studies. Goldenberg et al. (2001) increased mortality salience by having some subjects respond to questionnaires about death. This increased their ratings of disgust toward other animals and strengthened their preference for arguments about human exceptionalism. Soenke et al. (2018) reported that reminders of death made subjects more negative toward claims of dolphin intellectual superiority over humans. Lifshin et al. (2017) found that subliminal death primes caused participants to endorse the killing of animals, again suggesting that human abuse of other animals has a terror management function. These effects do not follow from negative primes in general; they are specific to primes about death.

Are humans capable of freeing ourselves from their basic fears? Becker's theories and the evidence for TMT have shown how deeply our mistreatment of other animals is rooted in our fear of death, but they have not provided a solution. I am skeptical that a radical change in human psychology is possible. But perhaps knowing the way we are can help induce us to adopt legal safeguards to protect other animals from our neurotic and destructive propensities. Now that would be unique.

\section{References}

Becker, E. (1973). The Denial of Death. New York: Free Press.

Chapman, C. A. and Huffman, M. A. (2018). Why do we want to think humans are different? Animal Sentience 23(1).

Goldenberg, J. L., Pyszczynski, T., Greenberg, J., Solomon, S., Kluck, B. and Kornwell, R. (2001). I am not an animal: Mortality salience, disgust, and the denial of human creatureliness. Journal of Experimental Psychology: General, 130(3), 427-435.

Greenberg, J., Solomon, S. and Arndt, J. (2008). A uniquely human motivation: Terror management. In Handbook of Motivation Science, 114-124, ed. J. Shah and W. Gardner. New York: Guilford Press.

Landau, M. J., Solomon, S., Pyszczynski, T. and Greenberg, J. (2007). On the compatibility of terror management theory and perspectives on human evolution. Evolutionary Psychology, 5(3), 476-519.

Lifshin, U., Greenberg, J., Zestcott, C. A. and Sullivan, D. (2017). The evil animal: A terror management theory perspective on the human tendency to kill animals. Personality and Social Psychology Bulletin, 43(6), 743-757.

Marino, L. and Mountain, M. (2015). Denial of death and the relationship between humans and other animals. Anthrozoös, 28(1), 5-21.

Soenke, M., Cohen, F., Greenberg, J. and Lifshin, U. (2018). Are you smarter than a cetacean?: Death reminders and concerns about human intelligence. Society \& Animals, 26(5), 469-489.

Solomon, S., Greenberg, J. and Pyszczynski, T. (1991). A terror-management theory of social behavior: The psychological functions of self-esteem and cultural worldviews. In Advances in Experimental Social Psychology, 91-159, ed. M. P. Zanna. San Diego: Academic Press.

Solomon, S., Greenberg, J. and Pyszczynski, T. (2004). The cultural animal: Twenty years of terror management theory and research. In Handbook of Experimental Existential Psychology, 13-34, ed. J. Greenberg, S. L. Koole and T. Pyszczynski. New York: Guilford Press. 